\title{
Development of Cognitive Aspects of Children in Matching Numbers with Number Symbols using a Combination of Demonstration, Make a Match Models Assisted by Audio Visual Media
}

\author{
Asrul Hidayat ${ }^{I}$ ", Sutarto Hadi ${ }^{2}$, Darmiyati ${ }^{2}$ \\ ${ }^{1}$ Universitas Islam Kalimantan Muhammad Arsyad Al Banjari, Banjarmasin 70123 Indonesia \\ ${ }^{2}$ Department of Early Childhood Education, Universitas Lambung Mangkurat, Banjarmasin 70123 Indonesia
}

\begin{tabular}{|c|c|}
\hline ARTICLE INFO & A B STRACT \\
\hline $\begin{array}{l}\text { Article history } \\
\text { Submission: October } 2019 \\
\text { Revised: January } 2020 \\
\text { Accepted: February } 2020 \\
\text { Keywords: Demonstration } \\
\text { Model, Make a Match, } \\
\text { Audio-Visual Media }\end{array}$ & $\begin{array}{l}\text { The purpose of this study was to describe teacher activities, children's activities and } \\
\text { the development of children's cognitive abilities in matching numbers with number } \\
\text { symbols using a combination of Demonstration, make a Match model, assisted by } \\
\text { Audio-Visual Media in group B of TK RA Citra Islami Banjarmasin. } \\
\text { This study uses a qualitative approach with a type of classroom action research } \\
\text { (CAR). Sources of data in this study were teacher and child group B of TK RA } \\
\text { Citra Islami Banjarmasin located on Jalan Kelayan B Komplek I0 Gang H. Thaberi } \\
\text { RT. I3 Banjarmasin. The research instrument used by researchers to retrieve data is } \\
\text { observation. } \\
\text { The results of this study illustrate that the teacher's activities have been carried out } \\
\text { according to the steps that have been set with very good criteria. Child activity } \\
\text { increases in each cycle with very active criteria. Development of cognitive aspects of } \\
\text { children in matching numbers with number symbols using a combination of } \\
\text { Demonstration, make a Match model, assisted by Audio-Visual Media in group B } \\
\text { TK RA Citra Islami Banjarmasin has improved with the criteria of developing very } \\
\text { well. } \\
\text { The suggestion of this study is expected to be a guideline in learning activities using } \\
\text { the combined Demonstration, Make a Match model, assisted by Audio-Visual } \\
\text { Media in an effort to improve the quality of learning on cognitive aspects and } \\
\text { provide input for subsequent researchers to be able to increase creativity in carrying } \\
\text { out the research process. }\end{array}$ \\
\hline & $\begin{array}{l}\text { (C) (1) (2) } \begin{array}{l}\text { (C) } 2019 \text { The Authors. Journal of K6, Education, and Management } \\
\text { (j-K6EM). ISSN: 2580-2135. Published by Graduated Program of } \\
\text { Educational Management, Universitas Lambung Mangkurat, }\end{array} \\
\text { Banjarmasin 70123, Indonesia. This is an open-access article under the CC-BY-SA license. }\end{array}$ \\
\hline
\end{tabular}




\section{Introduction}

Learning activities can not be separated from the role of teachers and students because both components are very important in the learning process. (Suriansyah \& Aslamiah, 2015). The role of educators is very important, because as individuals who are able to carry out educational actions in one educational situation in order to achieve educational goals. The teacher becomes one of the things that assesses the implementation of a learning strategy in the classroom. Creative, professional and exciting teachers are required to have developing skills approach and choose effective learning methods (Mulyasa, 2015).

Early childhood can also be referred to as the golden age. Children experience rapid growth and development during the golden age. (Santrock \& John, 2007) states that children aged 4 to 6 years of brain development are almost like adults. This will affect the response from the environment. The Golden Age concept is reinforced by the fact found by Neurologists who claim that when babies appear they carry 100-200 billion neurons or nerve cells that are ready to work between cells. At the age of children reaching the age of 3 years, the development of the mind network reaches $80 \%$. Whereas more and more adult children the development of the child's mind tissue is slowing down due to the increasing network of the mind.

The golden age only takes place I time throughout the human life span itself. This indicates how miserable a family is when it ignores the golden age of a child that is held in the early childhood education stage. Positive stimuli can give experience to children so that the development \& performance of the brain works optimally.

The fact that was found at RA TK Islamic Image Banjarmasin in Group B that the cognitive aspect growth in early childhood is not maximal, to the extent that children find it difficult to compare numbers with symbol numbers that occur at this time there is still no type of playing work in children that have not shown a real object which is the topic of the theme discussion that was carried out. (Safitri, Ibnu Ahmad \& Saleh, 2018). This makes the information obtained by the child still not clear enough and still not real.
By looking at the atmosphere, the information obtained by the child cannot be received. The impact of these matters is that children cannot recognize and separate the numbers five (5), six (6), eight (8), and (9) and do not understand how to compare the number or not a few objects with the number stage.

Data in the 2015-2016 training year out of I5 children, there were 4 children who could recognize and compare numbers with the number stage or "Develop according to expectations" (BSH), 4 children began to recognize and compare numbers with the number stage or "Start to Develop" (MB) and 6 children still cannot recognize and compare numbers with number or "Not Developing" (BB). The 2016-2017 training year data from 14 children, there were 2 children with the criteria of "Very Good Developing" (BSB), 2 children with the criteria of "Developing according to Expectations" (BSH), 7 children with the criteria of "Developing" \& 3 children with the criteria of "Not Developing" (BB) in recognizing and comparing numbers with number stages. Whereas for the training year 2018-2019, from 16 children, only 3 children were able to recognize and compare numbers with number symbols or "Develop according to expectations" (BSH), 5 children began to recognize and compare numbers with number symbols or "Start Developing "(MB) and the remaining 8 children cannot recognize and match numbers and symbol numbers or "Not Developing" (BB). The fact is that at this time because it was provoked by the growth of the era which increasingly accelerated until the objects needed by children for direct monitoring even faded to the point that the information obtained by children was increasingly minimal. Until now, children are not enough to get the opportunity to work on direct experience of real objects from the work carried out. If the matter is not cared for continuously, the children will not be able to know the object actually from the empirical thing it does.

This will have a negative impact on children, the weight of the quality of education itself for the future. Whereas in the activity, children themselves should be the main objects in working on activities, active children are not teachers. Thus, according to the above problem the analysis of the researcher to overcome the problem can be carried out using a combination 
of demonstration models, make a match by assisting audio-visual media such as videos about numbers and symbol numbers to something that the child sees as real. Of the many models, it is desirable cognitive children can increase in comparing numbers with symbol numbers and develop as optimally as possible.

Strategies to overcome cognitive problems in comparing numbers with symbol numbers with a combination of models. The combination itself combines a number of models in a way or medium.

From the description of the background of the problem, the researchers were most interested in analyzing "Cognitive Development of Children in Matching Numbers with Symbols of Numbers Using a Combination of Demonstration Models, Make A Match Assisted by Audio-Visual Media in Group B of RA Islamic Image Banjarmasin.2.

\section{Methodology}

This research approach uses a qualitative approach. Qualitative data, namely data in the form of sentence information that reflects the expression of children in connection with the level of understanding of a knowledge (cognitive), or student attitudes toward new ways of learning (affective), children's activities following lessons, attention in learning, beliefs self, spirit of learning, and the like, can be examined qualitatively (Kunandar, 2012).

The qualitative approach emphasizes the analysis of the processes of inductive thought processes that are related to the dynamics of the relationships between observed phenomena, and always with scientific logic. Qualitative approaches are meaningless without using support from quantitative data but are emphasized in the depth of the formal opinion of the researcher in responding to the problems faced (Gunawan \& imam, 2013).

This type of research is Classroom Action Research (CAR). Where is Classroom Action Research (CAR)? Based on information from Ebbut \& Hopkins (Kunandar, Classroom Action Research, 2012) is a systematic study of efforts to improve the practice of education by teachers by working on actions in learning, according to their reflections on the results of these actions.

This study uses Classroom Action Research (CAR) by working on actions in an effort to improve the cognitive aspects of the child in comparing numbers and symbols to the point that the cognitive aspects of the child develop as they should. Research into action classrooms (classroom action research) has a very urgent and strategic role to increase the quality of learning when implemented properly and correctly.

The event/event from this study was carried out in kindergarten RA Kindergarten Islamic image of Banjarmasin in Group B which was addressed at Jalan Kelayan B Komplek I0 Gang H. Thaberi RT. I3 Banjarmasin. The Kindergarten room consists of 4 rooms, consisting of 2 rooms in group A and 2 rooms in group B. This study aims to explore the strategies $\&$ teaching techniques of teachers in developing cognitive aspects of children in comparing numbers with number symbols using a combination of demonstration models and models. make a match \& audiovisual media. Researched Factors are teacher, two children and the results of children's cognitive development that are dominant to the kindergarten.

\section{Findings and Discussion}

Based on the findings obtained through the implementation of the teacher activity learning plan, children's activities, and the results of children's skills at each of the Ist meeting, 2nd meeting, 3rd meeting and 4th meeting, the following matters can be determined:

\section{a. Teacher Activity}

Based on the data from the above research results, the use of the demonstration model combined with the make a matching model assisted by audio - visual media in the B TK RA group Islamic image has been successful in increasing the learning outcomes of children in group B TK RA Citra Islami. It can be seen from the score that continues to grow to start from the first meeting score of 22 with the fairly good criteria of the second meeting of the score 25 with the criteria of the third meeting the score 28 with good criteria, and the fourth meeting score 33 with the best criteria.

Associated with the lesson on developing cognitive aspects in comparing numbers with number symbols to the point that it can be decided that at the meeting the teacher's activities in the implementation of learning have obtained optimal results. 
The teacher's activity increased in each meeting because the teacher was able to master the learning model applied by the teacher, namely the demonstration model combined with the assisted make a matching model audio-visual media \& even this is caused by reflection at the end of each meeting and can be corrected at the next meeting (Suriansyah, 2015).

In accordance with the applied indicators, the teacher's activities are said to be successful in implementing the demonstration model combined with the make a matching model assisted by audio-visual media when the teacher's activity gets the best criteria with a value range of 30-36. Thus, indicating that the teacher has been able to carry out learning by using the demonstration model combined with the make a matching model assisted by audio-visual media as expected.

There are still a number of activities in the Ist \& 2nd meetings which have not been maximally carried out, including in the work aspects. The teacher asks the child to listen to the demonstration and analyze it. got a score of 2 .

The process of doing reflection so that the teacher engages all children in working on reflection on learning. Meeting 2, meeting 3 \& meeting 4 are carried out repairs so that there is an addition in every aspect. The teacher always strives to increase the quality of learning by using the demonstration model combined with the make a matching model assisted by audio-visual media so that the teacher can add to the child's learning outcomes. Then a teacher tries to be able to make the atmosphere \& learning environment pleasant for children. Good learning can help improve children's activities \& children's learning outcomes because the success of teachers in learning work will support children's success in learning.

The teacher has mastered the learning model \& media applied because the teacher uses the demonstration model combined with the make a matching model assisted by audio-visual media $\&$ even this is caused by a reflection at the end of each meeting $\&$ can be corrected at the next meeting.

\section{Child Activities}

Based on observations of children's activities taking part in meeting $\mathrm{I}$, meeting 2 , meeting 3 and meeting 4 , the comparison of observational results of learning work shows that children's activities from meeting I to meeting 4 are witnessed from the criteria in meeting I with a percentage of classical $45 \%$ classified as criteria quite active, at meeting 2 with a percentage of $65 \%$ with active criteria, at meeting 3 with a percentage of $75 \%$ with active criteria, and at meeting 4 with a percentage of $86 \%$ with the most active criteria.

Increasing children's activities have begun to be active in learning work. This indicates that children's activities have begun to take part in learning work using the demonstration model combined with a matching model assisted by audio-visual media, but there are still a number of children who are not active enough and are quite active in participating in learning work.

This indicates that the results of the research on children's activities on children's attention in paying attention to the teacher's explanation, analyzing the picture, the courage of the child inside doing learning $\&$ motivation in comparing images have been maximally overall. (Purwanti et al., 2018).

This result was obtained because using the demonstration model combined with the make a matching model assisted by audio-visual media has been applied well for children $\&$ children who have been able to carry out well, this matter is proven because the results obtained by the child have reached the target. At the 4th meeting, all children were said to be successful in using the demonstration model combined with the make a matching model assisted by audio-visual media.

The implementation of learning on the results of observations of children's activities matches the facts in the field that get an additional percentage until they get the most active criteria. Increasing children's activeness is there when following learning, children's attention in paying attention to teacher's explanations, analyzing images, children's courage in doing learning $\&$ motivation in comparing images.

\section{Results of Children's Cognitive Development Ability}

The results of the evaluation of the learning process carried out in Cycle I \& Cycle II can be witnessed with the results of developing cognitive aspects of children in meeting I getting around $37.5 \%$, at meeting 2 around $56 \%$, at meeting 3 around $81 \%$. followed by meeting 4 around $94 \%$. That result means it has reached the expected indicators. 
Based on observations at meetings I, 2, 3 $\& 4$, it can be seen that teacher activities, children's activities \& children's learning outcomes have increased. That has reached a predetermined indicator of success.

Thus, this class action research is successful \& the hypothesis acknowledges that if cognitive aspects in comparing numbers with symbol numbers pass the demonstration model combined with a matching model assisted by audio-visual media in group B, RA Banjarmasin Islamic Image, the results of cognitive development will increase.

\section{Conclusion and Recommendation}

Based on the results of classroom action research (PTK) conducted on child group B TK RA Banjarmasin Islamic image in comparing numbers with symbol numbers through a demonstration model combined with a make match model assisted by audio-visual media conducted in the 2018-2019 school year in the second semester developed most significant. The results of class action research in Cycle I \& Cycle II can be decided as follows:

I. Teacher's activity in developing cognitive aspects in comparing numbers with symbol numbers combined with model make a match assisted by group B audio-visual media RA TK Islamic Image Banjarmasin has been carried out in accordance with the steps that have been decided with the best criteria.

2. Children's activities in learning to develop cognitive aspects in comparing numbers with number symbols through demonstration models combined with a make-match model assisted by RA Citra Islami Banjarmasin group B audio-visual media Banjarmasin felt an increase $n$ each cycle with the most active criteria.

3. The results of the development of the cognitive aspects of the child in comparing numbers with the number symbol through the demonstration model combined with the make-match model assisted by group B audio-visual media RA TK Islamic Image Banjarmasin felt an increase with the best developing criteria.

The use of the demonstration model combined with the make a matching model assisted by audio-visual media can develop cognitive aspects in matching numbers with the symbol of group B numbers RA TK Islamic Image Banjarmasin is set to succeed.

Based on the results of the research \& skills that have been described, the researcher presents a number of suggestions that need to be considered, including:

\section{For Teachers}

The results of this research can be used as a solution to developing cognitive learning, especially in comparing numbers with symbol numbers to the extent that in the process of practicing the learning process training varies more according to the needs of the child. In addition to this, the teacher can correct performance in training to increase his professionalism as a teacher.

2. For Principals (TK)

The results of this research are desired to be able to help the school principal (TK) as an input material to increase the quality of learning in improving the process $\&$ learning outcomes of children in school (TK) in order to increase the quality of education as much as possible.

3. For Other Researchers

The results of this research are desirable as a guideline in learning work using a demonstration model combined with a make a matching model assisted by audio-visual media in an effort to correct the quality of learning in cognitive aspects $\&$ provide input for subsequent researchers in order to increase creativity in developing the research process.

\section{References}

Gunawan, \& imam. (2013). Metode Penelitian Kualitatif. Jakarta: PT. Bumi Aksara.

Kunandar. (2012). Penelitian Tindakan Kelas. Jakarta: Raja Grafindo Persada.

Mulyasa. (2015). Revolusi Mental Dalam Pendidikan. Bandung : PT Remaja Rosdakarya.

Purwanti, R., Suriansyah, A., Aslamiah., \& Dalle, J. (2018). Introducing Language Aspect (English) to Early Childhood Through The Combination of Picture And Picture Model, Talking Stick Model, Flashcard Media, and Movement and Song Method in bI Group at Matahariku Bilingual Kindergarten Landasan Ulin Tengah Banjar. European 
Journal of Education Studies, 5 (7), I-7. doi: I0.528I/zenodo.I494188.

Safitri, M. E., Ibnu Ahmad, K., \& Saleh, M. (2018). Development of Child Independence Through. European Journal of Education Studies, 5 (7): I9.

Santrock \& John, W. (2007). Perkembangan Anak. Jakarta: Erlangga.

Suriansyah, A. (2015). Pengembangan Pembelajaran Berbasis Tik (proses dan permasalahannya). Jurnal Paradigma, IO(2), I-8.

Suriansyah, A., \& Aslamiah. (2015). Strategi kepemimpinan Kepala Sekolah, Guru, Orang tua, dan Masyarakat Dalam Membentuk Karakter Siswa . Cakrawala Pendidikan, 2013 (2), 34-38.doi: 10.21831/cp.v2i2.4828. 